Review

\title{
Imaging Techniques for Aortic Aneurysms and Dissections in Mice: Comparisons of Ex Vivo, In Situ, and Ultrasound Approaches
}

\author{
Sohei Ito ${ }^{1,2} \mathbb{D}$, Hong S. Lu ${ }^{1,2,3} \mathbb{D}$, Alan Daugherty ${ }^{1,2,3} \mathbb{D}^{\mathbb{D}}$ and Hisashi Sawada $1,2,3, * \mathbb{D}$ \\ 1 Saha Cardiovascular Research Center, College of Medicine, University of Kentucky, \\ Lexington, KY 40536, USA; sohei.ito@uky.edu (S.I.); hong.lu@uky.edu (H.S.L.); \\ alan.daugherty@uky.edu (A.D.) \\ 2 Saha Aortic Center, College of Medicine, University of Kentucky, Lexington, KY 40536, USA \\ 3 Department of Physiology, College of Medicine, University of Kentucky, Lexington, KY 40536, USA \\ * Correspondence: hisashi.sawada@uky.edu; Tel.: +1-859-218-1705
}

check for

updates

Citation: Ito, S.; Lu, H.S.; Daugherty, A.; Sawada, H. Imaging Techniques for Aortic Aneurysms and Dissections in Mice: Comparisons of Ex Vivo, In Situ, and Ultrasound Approaches. Biomolecules 2022, 12, 339. https://doi.org/10.3390/ biom12020339

Academic Editor: Vladimir N. Uversky

Received: 25 January 2022

Accepted: 16 February 2022

Published: 21 February 2022

Publisher's Note: MDPI stays neutral with regard to jurisdictional claims in published maps and institutional affiliations.

Copyright: (C) 2022 by the authors. Licensee MDPI, Basel, Switzerland. This article is an open access article distributed under the terms and conditions of the Creative Commons Attribution (CC BY) license (https:// creativecommons.org/licenses/by/ $4.0 /)$.

\begin{abstract}
Aortic aneurysms and dissections are life-threatening conditions that have a high risk for lethal bleeding and organ malperfusion. Many studies have investigated the molecular basis of these diseases using mouse models. In mice, ex vivo, in situ, and ultrasound imaging are major approaches to evaluate aortic diameters, a common parameter to determine the severity of aortic aneurysms. However, accurate evaluations of aortic dimensions by these imaging approaches could be challenging due to pathological features of aortic aneurysms. Currently, there is no standardized mode to assess aortic dissections in mice. It is important to understand the characteristics of each approach for reliable evaluation of aortic dilatations. In this review, we summarize imaging techniques used for aortic visualization in recent mouse studies and discuss their pros and cons. We also provide suggestions to facilitate the visualization of mouse aortas.
\end{abstract}

Keywords: imaging approach; aortic diseases; aortopathy; mouse

\section{Introduction}

Aortic aneurysms are defined as a permanent dilatation of the aortic wall that occurs commonly in the infrarenal abdominal or proximal thoracic region [1-3]. Aortic dissections are a tearing of the aortic wall, predominantly initiated in the thoracic region [1-4]. Aortic rupture and organ malperfusion are lethal consequences of these diseases [2-4]. There is no validated pharmacological approach to prevent or reduce aortic aneurysms and dissections (AADs). Thus, animal studies are needed to uncover the molecular basis of AADs for the development of new therapeutics. Over the past two decades, multiple mouse models have been established to investigate the mechanism of AADs. These include angiotensin II infusion, periaortic application of calcium chloride, intraluminal or periaortic elastase infusion, and $\beta$-aminopropionitrile administration [5-11]. Many molecular mechanisms have been investigated using these mouse models.

In humans, AADs are monitored by ultrasonography, computed tomographic (CT) angiography, or magnetic resonance imaging (MRI) [12,13]. In mice, aortic dimensions are evaluated mainly by three approaches; ex vivo, in situ images, and ultrasonography. Ex vivo and in situ approaches can visualize the aorta in any region directly and readily after termination without expensive imaging modality. Therefore, these approaches have been used widely in mouse AAD studies. With the advent of the high-frequency ultrasound system, aortic imaging in mice has evolved rapidly. Ultrasonography enables monitoring of the aorta in living mice $[14,15]$. Sequential evaluation is a considerable advantage of this mode. These three approaches have provided important insights into understanding the pathophysiology of AADs, while reliable evaluation of AADs in mice is often challenging 
because of multiple confounding factors, such as morphological alteration of the aorta and the interference by other organs. For authentic assessment of AADs, it is important to understand the strengths and weaknesses of each imaging approach.

In this review, we summarize the primary imaging modality for aortic visualization in recent mouse studies for AADs. We highlight ex vivo, in situ, and ultrasound approaches, discuss their pros and cons, and provide suggestions for aortic imaging in mice.

\section{Preferred Approaches for Aortic Imaging in Mice}

To determine imaging approaches that have been used for the determination of AADs in mice, we summarized recent articles using mouse AAD models. Articles were searched in PubMed with three keywords: "aortic aneurysm", "aortic dissection", or "aortopathy", published in Arteriosclerosis, Thrombosis, and Vascular Biology (ATVB) from 2015 to 2020. There were 131 articles in $A T V B$ during the interval, and 32 articles were excluded because those were not research articles (Figure 1A). There were 99 research articles associated with AADs and 78 articles that used AAD mouse models. A total of $49(63 \%)$ and $11(14 \%)$ articles studied abdominal aortic aneurysm (AAA) and thoracic aortic aneurysm (TAA) mouse models, respectively (Figure 1B). Four articles (5\%) used aortic dissection (AD) mouse models. Nine articles (12\%) investigated two aortic diseases, TAA and AAA ( 7 articles, $9 \%)$ or TAA and $\mathrm{AD}$ (2 articles, $3 \%)$.

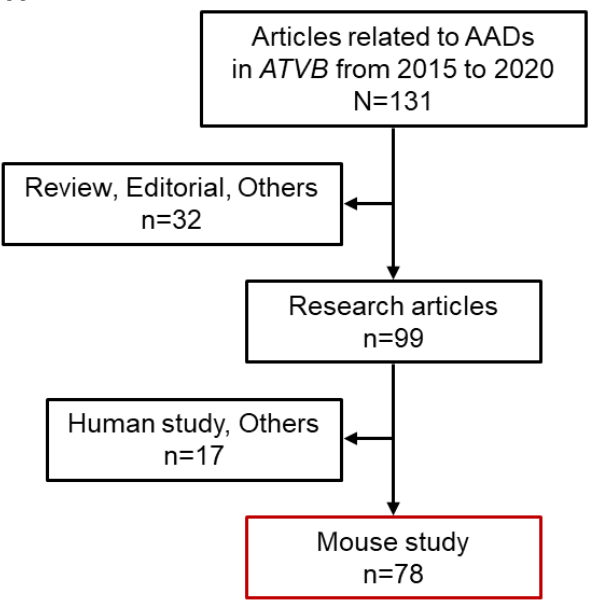

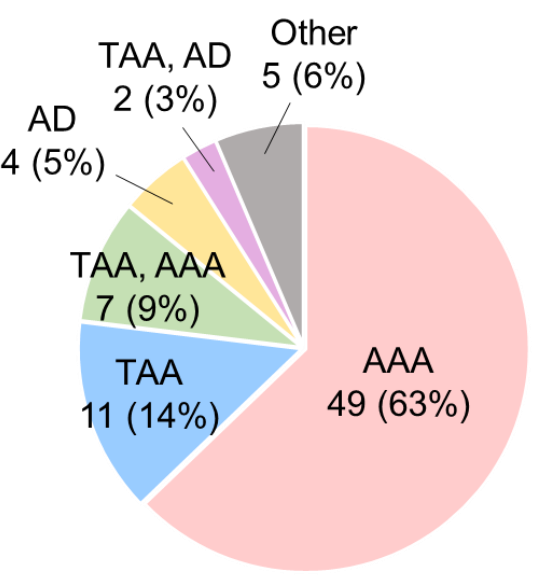

c

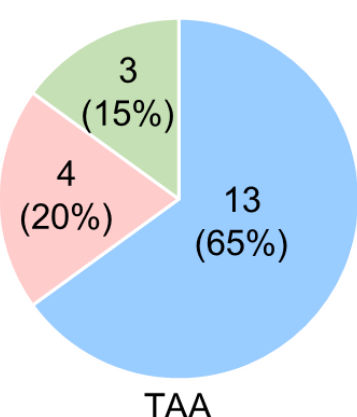

TAA

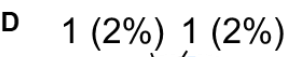

E
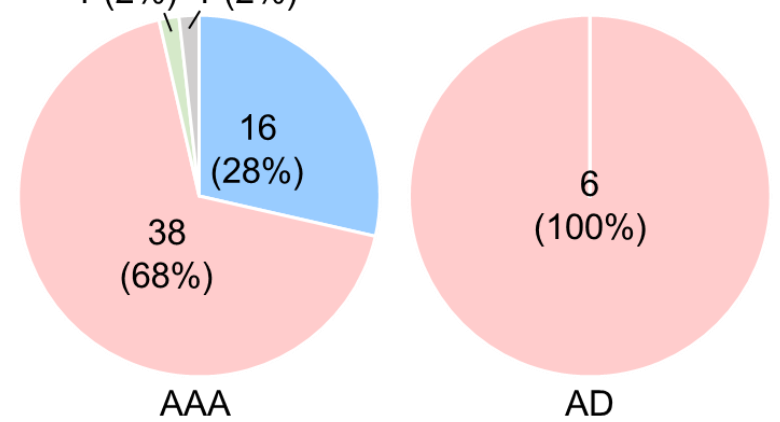

$\mathrm{AD}$

Ultrasonography

Direct imaging

(Ex vivo or in situ)

Histology

Not stated

Figure 1. Difference of the primary imaging approach in mouse studies for aortic diseases published in Arteriosclerosis, Thrombosis, and Vascular Biology (ATVB) from 2015 to 2020. (A) Schematic diagram for included or excluded articles in this review. (B) The number of articles of aortic studies published in ATVB from 2015 to 2020. Primary imaging approaches for the evaluation of (C) TAA, (D) AAA, and (E) AD. 


\subsection{Imaging Approaches for Aortic Aneurysms}

In 20 articles investigating TAAs, 13 studies (65\%) performed ultrasonography as the primary approach for aortic measurements (Figure 1C) [15-27]. Direct measurements using ex vivo or in situ images were performed in four studies (20\%) [28-31]. Three studies (15\%) evaluated aortic diameters histologically [32-34]. Conversely, direct imaging using ex vivo or in situ approach was the most common mode for AAA determination (38 articles, 68\%) [28-31,35-68], and ultrasonography was the second most common approach (16 articles, 28\%, Figure 1D) [25-27,69-81]. In these articles, 63 articles (96\%) measured aortic diameters as a parameter to describe the severity of aortic aneurysms.

The difference of preferred modes for aortic imaging between TAAs and AAAs may be based on differences in histological features in these diseases. Adventitial thickening with collagen deposition is a profound pathology in several AAA mouse models, including angiotensin II infusion [82]. Calcification and thrombus formation are also reported in AAA tissues $[82,83]$. Therefore, AAA structures are relatively maintained in aneurysmal mice even after termination, and it can be evaluated by direct approaches, including ex vivo and in situ approaches. In contrast, several TAA mouse models exhibit thinning of the aortic wall occasionally at the advanced stage of diseases [84,85]. Thus, aortic patency in TAA is often not maintained in mice with the absence of blood pressure after termination. In TAAs, aortic measurements by direct approaches have a potential of underestimation if the aortic patency is not maintained.

Several articles used histological images for aortic measurements. In these articles, aortic diameters were determined by measuring the longest distance between two points on the inner elastic laminae. Aortic perimeters were also measured by tracing the inner elastic laminae. However, measurement of aortic dimensions using tissue sections is unlikely to provide authentic diameters because the sample preparation will affect aortic measurements.

CT and MRI can also evaluate AADs in mice [86,87], but these modalities were used in only three articles of recent ATVB publications [18,28,44]. State-of-the-art micro-CT scanners have 0.5 to $5 \mu \mathrm{m}$ resolutions [88] and enable volumetric measurements with detailed spatial characterization. Thus, we anticipate that micro-CT scanning will be applied more frequently in the future in mouse AAD studies. However, there are several impediments to applying CT imaging as a standard approach. The requirement of a contrast agent is a considerable impediment. In addition, radiation exposure needs to be considered. Although the radiation dose may vary by modalities, scan areas, and resolutions, mice are exposed to radiation at about 0.3 to 0.5 Gy per scan [89]. The lethal radiation dose is 5.0 to $7.6 \mathrm{~Gy}$ in mice [89]. Given the lethality and organ damages by radiation, there are impediments to performing serial longitudinal CT scanning. Conversely, MRI does not need radiation. In addition, time-of-flight angiography and black-blood spin-echo sequences can evaluate aortic morphology without contrast enhancement $[90,91]$. Despite these technological advancements, MRI is not common for routine use because of the expense of the system and duration of image acquisition.

\subsection{Imaging of Aortic Dissections}

Although there were only six articles present in this literature survey, all articles investigating ADs used direct approaches as the primary mode (Figure 1E) [15,21,92-95]. In these articles, histological analyses were performed to validate the presence of ADs. In contrast to aneurysmal studies, none of the AD studies used aortic diameters to describe the disease severity. The incidence rate is a common mode to describe the development of ADs, but the definition of ADs is variable among studies [96].

There is no standardized mode to describe the severity of ADs. Two recent studies attempted to describe the severity of ADs by measuring either the length or extent of aortic hemorrhage in ex vivo images $[95,97]$. However, it is not feasible to discern adventitial hemorrhage from mild ADs by ex vivo visualization. Several articles used a scoring scale for AD severity from normal to aortic rupture, while it may be difficult to represent a modest 
change in this mode. Thus, it is desirable to develop objective and quantitative parameters for the evaluation of ADs. Recently, we reported that a high-frequency ultrasound system can detect false lumen and flap in mice with ADs [15]. Therefore, it is feasible to use ultrasonography for quantitative evaluation of AD formation in mice.

\section{Imaging Approaches for Aortic Measurements in Mice}

Ex vivo and in situ direct visualizations and ultrasonography were common modes for aortic imaging in mice. Of note, in 78 recent $A T V B$ articles, most studies used either mode for aortic visualization (Figure $1 \mathrm{C}-\mathrm{E}$ ). Each mode has different strengths and weaknesses. It is crucial to understand the characteristics of each mode for reliable imaging and accurate measurements.

\subsection{Ex Vivo Imaging}

The ex vivo approach can assess aortic morphology readily after termination without the need for expensive imaging modalities (Figure 2A). This approach can measure aortic dimensions at any region from the proximal thoracic to the distal abdominal aorta but is most commonly used for measurements of AAAs. Since ex vivo mode is optimal to evaluate the gross appearance of aortas, the presence of ADs and rupture is usually assessed by this mode. Despite the ease of use, there is a shortcoming that aortic measurements in this mode are affected by the lack of intraluminal pressure of the aorta. After termination, the intraluminal pressure is lost, which may cause underestimation of aortic diameters, especially in thoracic aortas with severe aneurysmal dilatations. Several articles used either formalin or latex perfusion in physiological pressures during terminations to overcome this shortcoming [95,97-101].

Dissection microscopy is used routinely for ex vivo imaging of mouse tissue, but several articles used unique modalities for detail imaging or functional evaluations of the aortic wall. Phased contrast X-ray tomographic microscopy can construct detailed 3-dimensional (3D) aortic images $[18,102,103]$. Optical coherence tomography with panoramic digital imaging can assess aortic thickness and stiffness in addition to aortic morphology [104].

A. Ex Vivo

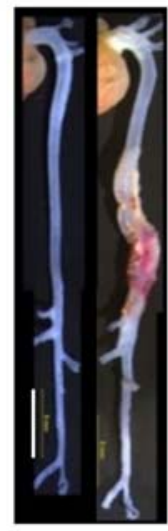

B. In Situ
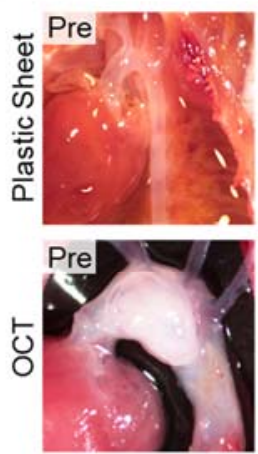
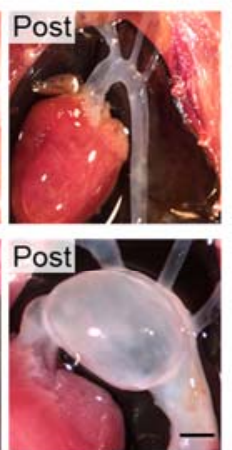

\section{Ultrasonography}

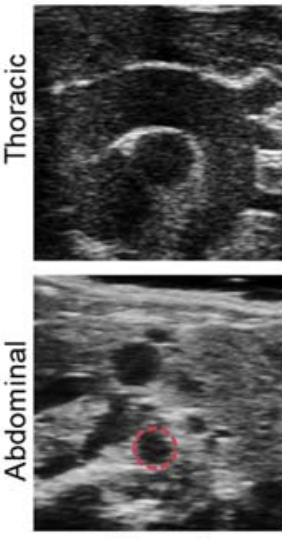

Normal

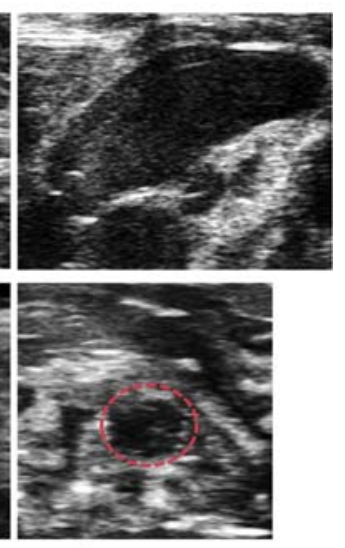

Aneurysm

Figure 2. Examples of aortic images in mice. Representative images of (A) ex vivo [95] and (B) in situ approaches (authors' unpublished data and the work of [105]), and (C) ultrasonography [14]. Ultrasound images were captured by Vevo 2100 with an MS550D (40 MHz). For in situ imaging, a piece of black plastic sheet was placed behind the aorta to enhance the contrast of the aortic wall. Subsequently, O.C.T. (optimal cutting temperature, 100-150 $\mu \mathrm{L}$ ) compound was injected from the left ventricle using an insulin syringe (31G). Scale bars in Figure (A) and (B) indicate 5 and $1 \mathrm{~mm}$, respectively. 


\subsection{In Situ Imaging}

In situ approach is less common for aortic visualization compared to ex vivo imaging, but it is a relatively rigorous mode to determine aortic dimensions in mice. In situ method can evaluate the aorta in the anatomical "in situ" position, which may enable more precise evaluation than the ex vivo approach (Figure 2B). However, it is often difficult to visually recognize the aorta in this mode because of the weak contrast of aortic edges (Figure 2B, top left). An approach to address this issue is an insertion of a black plastic sheet behind the aorta, which enhances the contrast of the aortic wall (Figure 2B, top right). Similar to ex vivo imaging, this mode also has the potential for underestimation in aortic measurements due to the absence of blood pressure. Recently, we reported a protocol for maintaining aortic patency by the injection of optimal cutting temperature (O.C.T.) compound [105]. Appropriate injection of O.C.T. does not cause excessive intraluminal pressure or overt tissue damage but maintains aortic patency to provide authentic aortic measurements (Figure 2B, bottom).

Although ex vivo and in situ approaches are practical modes for aortic measurements, these modes evaluate external, not luminal, diameters of the aorta. In AngIIinduced AAAs, external and luminal diameters are often different due to adventitial hemorrhages $[85,102,106]$. In addition, since these approaches are applied after euthanasia, sequential measurements are not feasible in these modes.

\subsection{Ultrasonography}

High-frequency ultrasound is a powerful tool to monitor aortic diameters sequentially in living mice (Figure 2C) $[14,107,108]$. Therefore, ultrasonography has been used widely in mouse AAD studies. In fact, $33 \mathrm{AAD}$ articles (45\%) in recent ATVB publications used ultrasonography to measure aortic dimensions. Despite the high versatility, there are several caveats in ultrasonography in terms of its system and settings.

The quality of ultrasound images depends on the ultrasound system, and the ultrasound view affects measurements. Therefore, it is important to describe detailed information of the ultrasound system and settings for rigor and reproducibility. Table 1 demonstrates the number of articles stating this information in recent ATVB articles. Most articles $(94 \%)$ state the ultrasound system used in the articles. The type of ultrasound transducer was stated in $38 \%$ of articles, and the specific frequency is described in $62 \%$ of articles. Surprisingly, the ultrasound view was stated only in $12 \%$ of articles. The information related to the cardiac cycle was described in only $35 \%$ of articles.

Table 1. Number of articles that stated the ultrasound system and settings.

\begin{tabular}{lccccc}
\hline & System & Transducer & Frequency & View & Cardiac Cycle \\
\hline $\begin{array}{c}\text { Number of } \\
\text { Articles (\%) }\end{array}$ & $32(94)$ & $13(38)$ & $21(62)$ & $4(12)$ & $12(35)$ \\
\hline
\end{tabular}

\subsubsection{Ultrasound System}

The ultrasound system, including a main unit and transducer, has a considerable impact on image quality. In general, higher frequency provides higher resolution. A highfrequency system is required in the AAD mouse study to detect $0.3-1.0 \mathrm{~mm}$ aortic dilatations. [6,85,100,109-111] Most studies in recent ATVB articles used high-frequency ultrasound systems, such as Vevo 2100 and 3100 (VisualSonics, FUJIFILM) with a highfrequency transducer (MS400: 18-38, MS550D: 22-55, MX550D: 25-55, MS700: 30-70 MHz). In contrast, human ultrasound systems use lower frequency compared to mouse ultrasound systems $(2-15 \mathrm{MHz})$. Thus, it is not recommended to use clinical systems for the visualization of mouse aortas because of insufficient spatial resolution. 


\subsubsection{Ultrasound View}

Ultrasound view is an important factor for accurate measurements of aortic diameters as aortic diameters may vary by ultrasound views (Figure 3A). The aorta is cylinder-shaped. Thus, the long-axis view has a potential for underestimation, while the short-axis view may cause overestimation. To capture appropriate aortic images, an ultrasound plane must be adjusted to the center and perpendicular to the aorta. For meaningful comparisons, aortic diameters must be measured in the same view and angle. Since ultrasonography is a user-dependent procedure, ultrasound procedures must be standardized for accurate visualizations of mouse aortas.

A

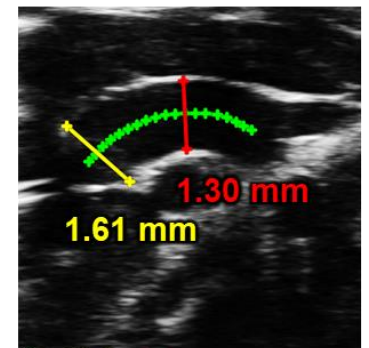

Right parasternal view

B

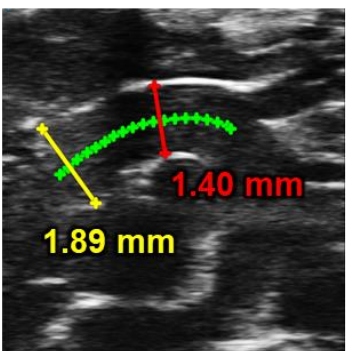

Systole

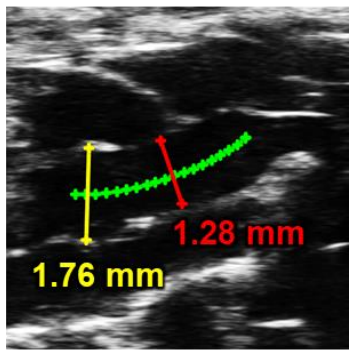

Left parasternal view

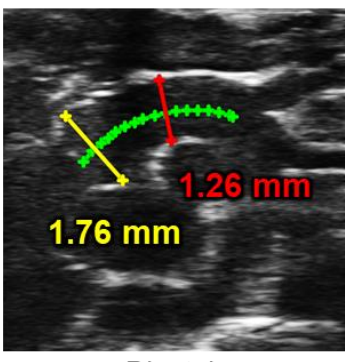

Diastole

Figure 3. Impacts of ultrasound view and cardiac phase on measurements of aortic diameters in mice. (A) Representative ultrasound images of right and left parasternal long-axis approaches in the proximal thoracic aorta. (B) Luminal diameters at the aortic root (yellow) and ascending aortic (red) were measured at the mid-systole and end-diastole in the right parasternal long-axis view. Green lines placed on the center of aortic lumen were used as a reference for aortic measurements. Authors' unpublished data. Ultrasound images were captured by Vevo 3100 with an MX550D (40 MHz).

In the thoracic aorta, the right parasternal long-axis view is optimal for ascending aortic imaging, whereas the left parasternal long-axis view is appropriate for the aortic sinus and proximal ascending aorta [14]. The descending aorta can be visualized by the paraspinal long- and short-axis views [15]. However, ultrasound imaging of the proximal descending aorta is technically difficult due to the interference of the occipital region with the transducer. In the abdominal aorta, ultrasound images have been captured from the ventral side in either a long- or short-axis view [14]. Since AAA formation is not often concentric, in particular the AngII model, the short-axis view is optimal to measure aortic diameters in the abdominal region [107]. The short-axis view can determine aortic areas in addition to dimensions.

\subsubsection{Cardiac Cycle}

The cardiac cycle affects aortic measurements (Figure 3B). Several articles used the difference of aortic diameters between cardiac phases to calculate aortic stiffness and strain $[25,112,113]$. To define the cardiac cycle, an electrocardiogram is commonly used during ultrasonography. Most articles measured aortic diameters at either end-diastole or mid-systole. The end-diastole is defined at the $\mathrm{R}$ wave, while the mid-systole is technically 
difficult due to the lack of clarity in the $\mathrm{T}$ wave. Therefore, several articles defined the mid-systole when the aorta is maximally and visually dilated. Because of the difference during the cardiac cycle, aortic diameters must be measured at a consistent cardiac phase. Since anesthesia can alter the cardiac function and hemodynamic state, it is also vital to adjust the anesthesia in an appropriate depth.

\subsubsection{Three-Dimensional Imaging}

Although specific units are required, several ultrasound systems can visualize mouse aortas in 3D [114-116]. Three-dimensional imaging enables the evaluation of aortic geometry more precisely, and 3D volumetric measurements can detect aortic dilatations at the earlier time point during AAA formation compared to 2D measurements [108]. Aortic imaging in 3D alleviates many issues associated with probe position and operator dependence. In addition, current ultrasound systems can obtain 3D images over time that assess aortic kinematics and strain [117].

\subsubsection{Doppler Ultrasonography}

Doppler ultrasound approaches assist the definition of AAD characteristics. Color and power Doppler modes visualize blood flow patterns, and irregular flow patterns have been reported in aneurysmal and dissected mouse aortas [103,118,119]. Pulse wave Doppler can measure flow velocities in aortas, and aortic flow velocities are decreased in several types of aneurysm mouse models [120-122]. In addition, pulse wave velocities can be used for the evaluation of aortic stiffness [120,123,124]. Of interest, pulse wave propagation and velocities can be mapped in 2D ultrasound views $[125,126]$.

\section{Comparisons of Ex Vivo, In Situ, and Ultrasound Approaches}

Characteristics of each imaging approach are summarized in Table 2. Direct visualization by ex vivo or in situ approaches does not need expensive devices. In addition, an in situ approach can image aortas in the original anatomical position. However, these modes can only be performed after termination. Ultrasound can measure aortic diameters sequentially in living mice, thereby overcoming the shortcomings of ex vivo and in situ approaches. Ultrasound imaging is becoming more common in mouse AAD studies, but it is technically challenging for the proximal descending aorta. Several mouse models show TAA formation in this region $[9,11,97,111]$. Thus, it is optimal to perform both in situ and ultrasound imaging for the determination of AADs. The combination of direct approach and ultrasonography compensates for each other and would provide more robust and accurate measurements.

Table 2. Comparison of ex vivo, in situ, and ultrasound approaches for aortic imaging in mice.

\begin{tabular}{ccccc}
\hline Approach & $\begin{array}{c}\text { Device } \\
\text { Cost }\end{array}$ & $\begin{array}{c}\text { Aortic } \\
\text { Position }\end{array}$ & $\begin{array}{c}\text { Sequential } \\
\text { Imaging }\end{array}$ & $\begin{array}{c}\text { Visible } \\
\text { Region }\end{array}$ \\
\hline Ex vivo & Low & Artificial & Not feasible & Unlimited \\
In situ & Low & Physiological & Not feasible & Unlimited \\
Ultrasound & High & Physiological & Feasible & Limited \\
\hline
\end{tabular}

\section{Limitations}

This review has a limitation that articles were searched in a single journal within a restricted period. In this review, $A T V B$ was chosen because of its large number of studies on aortic diseases in combination with its emphasis on rigor and reproducibility in preclinical research. To review common approaches for aortic imaging in current mouse studies, articles from 2015 through 2020 in ATVB were analyzed. A further review in other journals within an expanded period would enhance the suggestions and recommendations of this review to facilitate reliable evaluations of AADs in mice. 


\section{Summary}

This review summarized imaging approaches for the determination of mouse AADs in recent articles published in $A T V B$. Although multiple cutting-edge modalities are available for aortic imaging, ultrasonography, and direct ex vivo or in situ visualization are common techniques in mouse AAD studies. Since uncovering the mechanism of AADs relies on accurate aortic measurements, it is important to understand the feature of each imaging approach for authentic evaluation of AADs.

Funding: The authors' aortic aneurysm-related research work is supported by the National Heart, Lung, and Blood Institute of the National Institutes of Health (R35HL155649) and the American Heart Association SFRN in Vascular Disease (18SFRN33900001). The content in this commentary is solely the responsibility of the authors and does not necessarily represent the official views of the National Institutes of Health.

Conflicts of Interest: The authors declare no conflict of interest.

\section{References}

1. Shen, Y.H.; LeMaire, S.A.; Webb, N.R.; Cassis, L.A.; Daugherty, A.; Lu, H.S. Aortic Aneurysms and Dissections Series. Arterioscler. Thromb. Vasc. Biol. 2020, 40, e37-e46. [CrossRef] [PubMed]

2. $\quad$ Sakalihasan, N.; Michel, J.B.; Katsargyris, A.; Kuivaniemi, H.; Defraigne, J.O.; Nchimi, A.; Powell, J.T.; Yoshimura, K.; Hultgren, R. Abdominal aortic aneurysms. Nat. Rev. Dis. Primers 2018, 4, 34. [CrossRef] [PubMed]

3. Milewicz, D.M.; Ramirez, F. Therapies for thoracic aortic aneurysms and acute aortic dissections. Arterioscler. Thromb. Vasc. Biol. 2019, 39, 126-136. [CrossRef] [PubMed]

4. $\quad$ Nienaber, C.A.; Clough, R.E.; Sakalihasan, N.; Suzuki, T.; Gibbs, R.; Mussa, F.; Jenkins, M.P.; Thompson, M.M.; Evangelista, A.; Yeh, J.S.; et al. Aortic dissection. Nat. Rev. Dis. Primers 2016, 2, 16053. [CrossRef] [PubMed]

5. Daugherty, A.; Manning, M.W.; Cassis, L.A. Angiotensin II promotes atherosclerotic lesions and aneurysms in apolipoprotein E-deficient mice. J. Clin. Investig. 2000, 105, 1605-1612. [CrossRef] [PubMed]

6. Longo, G.M.; Xiong, W.; Greiner, T.C.; Zhao, Y.; Fiotti, N.; Baxter, B.T. Matrix metalloproteinases 2 and 9 work in concert to produce aortic aneurysms. J. Clin. Investig. 2002, 110, 625-632. [CrossRef] [PubMed]

7. Pyo, R.; Lee, J.K.; Shipley, J.M.; Curci, J.A.; Mao, D.; Ziporin, S.J.; Ennis, T.L.; Shapiro, S.D.; Senior, R.M.; Thompson, R.W. Targeted gene disruption of matrix metalloproteinase- 9 (gelatinase B) suppresses development of experimental abdominal aortic aneurysms. J. Clin. Investig. 2000, 105, 1641-1649. [CrossRef] [PubMed]

8. Bhamidipati, C.M.; Mehta, G.S.; Lu, G.; Moehle, C.W.; Barbery, C.; DiMusto, P.D.; Laser, A.; Kron, I.L.; Upchurch, G.R., Jr.; Ailawadi, G. Development of a novel murine model of aortic aneurysms using peri-adventitial elastase. Surgery 2012, 152, 238-246. [CrossRef]

9. Kanematsu, Y.; Kanematsu, M.; Kurihara, C.; Tsou, T.L.; Nuki, Y.; Liang, E.I.; Makino, H.; Hashimoto, T. Pharmacologically induced thoracic and abdominal aortic aneurysms in mice. Hypertension 2010, 55, 1267-1274. [CrossRef] [PubMed]

10. Kurihara, T.; Shimizu-Hirota, R.; Shimoda, M.; Adachi, T.; Shimizu, H.; Weiss, S.J.; Itoh, H.; Hori, S.; Aikawa, N.; Okada, Y. Neutrophil-derived matrix metalloproteinase 9 triggers acute aortic dissection. Circulation 2012, 126, 3070-3080. [CrossRef]

11. Ren, W.; Liu, Y.; Wang, X.; Jia, L.; Piao, C.; Lan, F.; Du, J. beta-Aminopropionitrile monofumarate induces thoracic aortic dissection in C57BL/ 6 mice. Sci. Rep. 2016, 6, 28149. [CrossRef]

12. Erbel, R.; Aboyans, V.; Boileau, C.; Bossone, E.; Bartolomeo, R.D.; Eggebrecht, H.; Evangelista, A.; Falk, V.; Frank, H.; Gaemperli, O.; et al. 2014 ESC Guidelines on the diagnosis and treatment of aortic diseases: Document covering acute and chronic aortic diseases of the thoracic and abdominal aorta of the adult. The Task Force for the Diagnosis and Treatment of Aortic Diseases of the European Society of Cardiology (ESC). Eur. Heart J. 2014, 35, 2873-2926. [PubMed]

13. Hong, H.; Yang, Y.; Liu, B.; Cai, W. Imaging of Abdominal Aortic Aneurysm: The present and the future. Curr. Vasc. Pharm. 2010, 8, 808-819. [CrossRef] [PubMed]

14. Sawada, H.; Chen, J.Z.; Wright, B.C.; Moorleghen, J.J.; Lu, H.S.; Daugherty, A. Ultrasound imaging of the thoracic and abdominal aorta in mice to determine aneurysm dimensions. J. Vis. Exp. 2019, 145, e59013. [CrossRef] [PubMed]

15. Sawada, H.; Franklin, M.K.; Moorleghen, J.J.; Howatt, D.A.; Kukida, M.; Lu, H.S.; Daugherty, A. Ultrasound monitoring of descending aortic aneurysms and dissections in mice. Arterioscler. Thromb. Vasc. Biol. 2020, 40, 2557-2559. [CrossRef] [PubMed]

16. Cook, J.R.; Clayton, N.P.; Carta, L.; Galatioto, J.; Chiu, E.; Smaldone, S.; Nelson, C.A.; Cheng, S.H.; Wentworth, B.M.; Ramirez, F. Dimorphic effects of transforming growth factor-beta signaling during aortic aneurysm progression in mice suggest a combinatorial therapy for Marfan syndrome. Arterioscler. Thromb. Vasc. Biol. 2015, 35, 911-917. [CrossRef] [PubMed]

17. Emrich, F.C.; Okamura, H.; Dalal, A.R.; Penov, K.; Merk, D.R.; Raaz, U.; Hennigs, J.K.; Chin, J.T.; Miller, M.O.; Pedroza, A.J.; et al. Enhanced caspase activity contributes to aortic wall remodeling and early aneurysm development in a murine model of Marfan syndrome. Arterioscler. Thromb. Vasc. Biol. 2015, 35, 146-154. [CrossRef] [PubMed] 
18. Trachet, B.; Piersigilli, A.; Fraga-Silva, R.A.; Aslanidou, L.; Sordet-Dessimoz, J.; Astolfo, A.; Stampanoni, M.F.; Segers, P.; Stergiopulos, N. Ascending aortic aneurysm in angiotensin II-infused mice: Formation, progression, and the role of focal dissections. Arterioscler. Thromb. Vasc. Biol. 2016, 36, 673-681. [CrossRef] [PubMed]

19. Galatioto, J.; Caescu, C.I.; Hansen, J.; Cook, J.R.; Miramontes, I.; Iyengar, R.; Ramirez, F. Cell type-specific contributions of the angiotensin II type 1a receptor to aorta homeostasis and aneurysmal disease-brief report. Arterioscler. Thromb. Vasc. Biol. 2018, 38 , 588-591. [CrossRef] [PubMed]

20. Fava, M.; Barallobre-Barreiro, J.; Mayr, U.; Lu, R.; Didangelos, A.; Baig, F.; Lynch, M.; Catibog, N.; Joshi, A.; Barwari, T.; et al. Role of ADAMTS-5 in Aortic Dilatation and Extracellular Matrix Remodeling. Arterioscler. Thromb. Vasc. Biol. 2018, 38, 1537-1548. [CrossRef] [PubMed]

21. Huang, X.; Yue, Z.; Wu, J.; Chen, J.; Wang, S.; Wu, J.; Ren, L.; Zhang, A.; Deng, P.; Wang, K.; et al. MicroRNA-21 Knockout Exacerbates Angiotensin II-Induced Thoracic Aortic Aneurysm and Dissection in Mice With Abnormal Transforming Growth Factor-beta-SMAD3 Signaling. Arterioscler. Thromb. Vasc. Biol. 2018, 38, 1086-1101. [CrossRef]

22. Zhou, Z.; Peters, A.M.; Wang, S.; Janda, A.; Chen, J.; Zhou, P.; Arthur, E.; Kwartler, C.S.; Milewicz, D.M. Reversal of Aortic Enlargement Induced by Increased Biomechanical Forces Requires AT1R Inhibition in Conjunction With AT2R Activation. Arterioscler. Thromb. Vasc. Biol. 2019, 39, 459-466. [CrossRef] [PubMed]

23. Pedroza, A.J.; Tashima, Y.; Shad, R.; Cheng, P.; Wirka, R.; Churovich, S.; Nakamura, K.; Yokoyama, N.; Cui, J.Z.; Iosef, C.; et al. Single-cell transcriptomic profiling of vascular smooth muscle cell phenotype modulation in Marfan syndrome aortic aneurysm. Arterioscler. Thromb. Vasc. Biol. 2020, 40, 2195-2211. [CrossRef]

24. Hibender, S.; Franken, R.; van Roomen, C.; Ter Braake, A.; van der Made, I.; Schermer, E.E.; Gunst, Q.; van den Hoff, M.J.; Lutgens, E.; Pinto, Y.M.; et al. Resveratrol inhibits aortic root dilatation in the Fbn1C1039G/+ Marfan mouse model. Arterioscler. Thromb. Vasc. Biol. 2016, 36, 1618-1626. [CrossRef] [PubMed]

25. Shen, M.; Lee, J.; Basu, R.; Sakamuri, S.S.V.P.; Wang, X.; Fan, D.; Kassiri, Z. Divergent role of matrix metalloproteinase 2 in pathogenesis of thoracic aortic aneurysm. Arterioscler. Thromb. Vasc. Biol. 2015, 35, 888-898. [CrossRef]

26. Lutshumba, J.; Liu, S.; Zhong, Y.; Hou, T.; Daugherty, A.; Lu, H.; Guo, Z.; Gong, M.C. Deletion of BMAL1 in smooth muscle cells protects mice from abdominal aortic aneurysms. Arterioscler. Thromb. Vasc. Biol. 2018, 38, 1063-1075. [CrossRef] [PubMed]

27. AlSiraj, Y.; Thatcher, S.E.; Blalock, E.; Saintilnord, W.N.; Daugherty, A.; Lu, H.S.; Luo, W.; Shen, Y.H.; LeMaire, S.A.; Arnold, A.P.; et al. Monosomy $\mathrm{X}$ in female mice influences the regional formation and augments the severity of angiotensin II-induced aortopathies. Arterioscler. Thromb. Vasc. Biol. 2021, 41, 269-283. [CrossRef]

28. Davis, F.M.; Rateri, D.L.; Balakrishnan, A.; Howatt, D.A.; Strickland, D.K.; Muratoglu, S.C.; Haggerty, C.M.; Fornwalt, B.K.; Cassis, L.A.; Daugherty, A. Smooth muscle cell deletion of low-density lipoprotein receptor-related protein 1 augments angiotensin II-induced superior mesenteric arterial and ascending aortic aneurysms. Arterioscler. Thromb. Vasc. Biol. 2015, 35, 155-162. [CrossRef]

29. Krishna, S.M.; Seto, S.W.; Jose, R.J.; Li, J.; Morton, S.K.; Biros, E.; Wang, Y.; Nsengiyumva, V.; Lindeman, J.H.; Loots, G.G.; et al. Wnt Signaling Pathway Inhibitor Sclerostin Inhibits Angiotensin II-Induced Aortic Aneurysm and Atherosclerosis. Arterioscler. Thromb. Vasc. Biol. 2017, 37, 553-566. [CrossRef] [PubMed]

30. Angelov, S.N.; Hu, J.H.; Wei, H.; Airhart, N.; Shi, M.; Dichek, D.A. TGF-beta (Transforming Growth Factor-beta) Signaling Protects the Thoracic and Abdominal Aorta From Angiotensin II-Induced Pathology by Distinct Mechanisms. Arterioscler. Thromb. Vasc. Biol. 2017, 37, 2102-2113. [CrossRef]

31. Wu, D.; Ren, P.; Zheng, Y.; Zhang, L.; Xu, G.; Xie, W.; Lloyd, E.E.; Zhang, S.; Zhang, Q.; Curci, J.A.; et al. NLRP3 (Nucleotide Oligomerization Domain-Like Receptor Family, Pyrin Domain Containing 3)-Caspase-1 Inflammasome Degrades Contractile Proteins: Implications for Aortic Biomechanical Dysfunction and Aneurysm and Dissection Formation. Arterioscler. Thromb. Vasc. Biol. 2017, 37, 694-706. [CrossRef] [PubMed]

32. Hu, J.H.; Wei, H.; Jaffe, M.; Airhart, N.; Du, L.; Angelov, S.N.; Yan, J.; Allen, J.K.; Kang, I.; Wight, T.N.; et al. Postnatal deletion of the type II transforming growth factor-beta receptor in smooth muscle cells causes severe aortopathy in mice. Arterioscler. Thromb. Vasc. Biol. 2015, 35, 2647-2656. [CrossRef] [PubMed]

33. McNeill, E.; Iqbal, A.J.; Jones, D.; Patel, J.; Coutinho, P.; Taylor, L.; Greaves, D.R.; Channon, K.M. Tracking Monocyte Recruitment and Macrophage Accumulation in Atherosclerotic Plaque Progression Using a Novel hCD68GFP/ApoE-/- Reporter Mouse-Brief Report. Arterioscler. Thromb. Vasc. Biol. 2017, 37, 258-263. [CrossRef] [PubMed]

34. Shin, S.J.; Hang, H.T.; Thang, B.Q.; Shimoda, T.; Sakamoto, H.; Osaka, M.; Hiramatsu, Y.; Yamashiro, Y.; Yanagisawa, H. Role of PAR1-Egr1 in the Initiation of Thoracic Aortic Aneurysm in Fbln4-Deficient Mice. Arterioscler. Thromb. Vasc. Biol. 2020, 40, 1905-1917. [CrossRef]

35. Mellak, S.; Ait-Oufella, H.; Esposito, B.; Loyer, X.; Poirier, M.; Tedder, T.F.; Tedgui, A.; Mallat, Z.; Potteaux, S. Angiotensin II Mobilizes Spleen Monocytes to Promote the Development of Abdominal Aortic Aneurysm in Apoe-/- Mice. Arterioscler. Thromb. Vasc. Biol. 2015, 35, 378-388. [CrossRef] [PubMed]

36. Lu, W.W.; Jia, L.X.; Ni, X.Q.; Zhao, L.; Chang, J.R.; Zhang, J.S.; Hou, Y.L.; Zhu, Y.; Guan, Y.F.; Yu, Y.R.; et al. Intermedin1-53 Attenuates Abdominal Aortic Aneurysm by Inhibiting Oxidative Stress. Arterioscler. Thromb. Vasc. Biol. 2016, 36, $2176-2190$. [CrossRef]

37. Alsiraj, Y.; Thatcher, S.E.; Blalock, E.; Fleenor, B.; Daugherty, A.; Cassis, L.A. Sex chromosome complement defines diffuse versus focal angiotensin II-induced aortic pathology. Arterioscler. Thromb. Vasc. Biol. 2018, 38, 143-153. [CrossRef] 
38. Takei, Y.; Tanaka, T.; Kent, K.C.; Yamanouchi, D. Osteoclastogenic Differentiation of Macrophages in the Development of Abdominal Aortic Aneurysms. Arterioscler. Thromb. Vasc. Biol. 2016, 36, 1962-1971. [CrossRef]

39. Moran, C.S.; Rush, C.M.; Dougan, T.; Jose, R.J.; Biros, E.; Norman, P.E.; Gera, L.; Golledge, J. Modulation of Kinin B2 Receptor Signaling Controls Aortic Dilatation and Rupture in the Angiotensin II-Infused Apolipoprotein E-Deficient Mouse. Arterioscler. Thromb. Vasc. Biol. 2016, 36, 898-907. [CrossRef]

40. Wang, K.C.; Li, Y.H.; Shi, G.Y.; Tsai, H.W.; Luo, C.Y.; Cheng, M.H.; Ma, C.Y.; Hsu, Y.Y.; Cheng, T.L.; Chang, B.I.; et al. MembraneBound Thrombomodulin Regulates Macrophage Inflammation in Abdominal Aortic Aneurysm. Arterioscler. Thromb. Vasc. Biol. 2015, 35, 2412-2422. [CrossRef]

41. Sawada, H.; Hao, H.; Naito, Y.; Oboshi, M.; Hirotani, S.; Mitsuno, M.; Miyamoto, Y.; Hirota, S.; Masuyama, T. Aortic iron overload with oxidative stress and inflammation in human and murine abdominal aortic aneurysm. Arterioscler. Thromb. Vasc. Biol. 2015, 35, 1507-1514. [CrossRef]

42. Usui, F.; Shirasuna, K.; Kimura, H.; Tatsumi, K.; Kawashima, A.; Karasawa, T.; Yoshimura, K.; Aoki, H.; Tsutsui, H.; Noda, T.; et al. Inflammasome Activation by Mitochondrial Oxidative Stress in Macrophages Leads to the Development of Angiotensin II-Induced Aortic Aneurysm. Arterioscler. Thromb. Vasc. Biol. 2015, 35, 127-136. [CrossRef]

43. Liu, J.; Lu, H.; Howatt, D.A.; Balakrishnan, A.; Moorleghen, J.J.; Sorci-Thomas, M.; Cassis, L.A.; Daugherty, A. Associations of apoAI and apoB-containing lipoproteins with AngII-induced abdominal aortic aneurysms in mice. Arterioscler. Thromb. Vasc. Biol. 2015, 35, 1826-1834. [CrossRef] [PubMed]

44. Wakita, D.; Kurashima, Y.; Crother, T.R.; Noval Rivas, M.; Lee, Y.; Chen, S.; Fury, W.; Bai, Y.; Wagner, S.; Li, D.; et al. Role of Interleukin-1 Signaling in a Mouse Model of Kawasaki Disease-Associated Abdominal Aortic Aneurysm. Arterioscler. Thromb. Vasc. Biol. 2016, 36, 886-897. [CrossRef] [PubMed]

45. Lu, H.; Howatt, D.A.; Balakrishnan, A.; Graham, M.J.; Mullick, A.E.; Daugherty, A. Hypercholesterolemia induced by a PCSK9 gain-of-function mutation augments angiotensin II-induced abdominal aortic aneurysms in C57BL/6 mice. Arterioscler. Thromb. Vasc. Biol. 2016, 36, 1753-1757. [CrossRef] [PubMed]

46. Schaheen, B.; Downs, E.A.; Serbulea, V.; Almenara, C.C.; Spinosa, M.; Su, G.; Zhao, Y.; Srikakulapu, P.; Butts, C.; McNamara, C.A.; et al. B-cell depletion promotes aortic infiltration of immunosuppressive cells and is protective of experimental aortic aneurysm. Arterioscler. Thromb. Vasc. Biol. 2016, 36, 2191-2202. [CrossRef]

47. Imanishi, M.; Chiba, Y.; Tomita, N.; Matsunaga, S.; Nakagawa, T.; Ueno, M.; Yamamoto, K.; Tamaki, T.; Tomita, S. Hypoxiainducible factor-1alpha in smooth muscle cells protects against aortic aneurysms-Brief Report. Arterioscler. Thromb. Vasc. Biol. 2016, 36, 2158-2162. [CrossRef]

48. Howatt, D.A.; Balakrishnan, A.; Moorleghen, J.J.; Muniappan, L.; Rateri, D.L.; Uchida, H.A.; Takano, J.; Saido, T.C.; Chishti, A.H.; Baud, L.; et al. Leukocyte Calpain Deficiency Reduces Angiotensin II-Induced Inflammation and Atherosclerosis But Not Abdominal Aortic Aneurysms in Mice. Arterioscler. Thromb. Vasc. Biol. 2016, 36, 835-845. [CrossRef]

49. Sharma, A.K.; Salmon, M.D.; Lu, G.; Su, G.; Pope, N.H.; Smith, J.R.; Weiss, M.L.; Upchurch, G.R.J. Mesenchymal Stem Cells Attenuate NADPH Oxidase-Dependent High Mobility Group Box 1 Production and Inhibit Abdominal Aortic Aneurysms. Arterioscler. Thromb. Vasc. Biol. 2016, 36, 908-918. [CrossRef]

50. Liu, C.L.; Wang, Y.; Liao, M.; Wemmelund, H.; Ren, J.; Fernandes, C.; Zhou, Y.; Sukhova, G.K.; Lindholt, J.S.; Johnsen, S.P.; et al Allergic Lung Inflammation Aggravates Angiotensin II-Induced Abdominal Aortic Aneurysms in Mice. Arterioscler. Thromb. Vasc. Biol. 2016, 36, 69-77. [CrossRef]

51. Martorell, S.; Hueso, L.; Gonzalez-Navarro, H.; Collado, A.; Sanz, M.J.; Piqueras, L. Vitamin D Receptor Activation Reduces Angiotensin-II-Induced Dissecting Abdominal Aortic Aneurysm in Apolipoprotein E-Knockout Mice. Arterioscler. Thromb. Vasc. Biol. 2016, 36, 1587-1597. [CrossRef] [PubMed]

52. Yan, Y.F.; Pei, J.F.; Zhang, Y.; Zhang, R.; Wang, F.; Gao, P.; Zhang, Z.Q.; Wang, T.T.; She, Z.G.; Chen, H.Z.; et al. The Paraoxonase Gene Cluster Protects Against Abdominal Aortic Aneurysm Formation. Arterioscler. Thromb. Vasc. Biol. 2017, 37, 291-300. [CrossRef] [PubMed]

53. Harada, T.; Yoshimura, K.; Yamashita, O.; Ueda, K.; Morikage, N.; Sawada, Y.; Hamano, K. Focal Adhesion Kinase Promotes the Progression of Aortic Aneurysm by Modulating Macrophage Behavior. Arterioscler. Thromb. Vasc. Biol. 2017, 37, 156-165. [CrossRef] [PubMed]

54. Nakao, T.; Horie, T.; Baba, O.; Nishiga, M.; Nishino, T.; Izuhara, M.; Kuwabara, Y.; Nishi, H.; Usami, S.; Nakazeki, F.; et al. Genetic Ablation of MicroRNA-33 Attenuates Inflammation and Abdominal Aortic Aneurysm Formation via Several Anti-Inflammatory Pathways. Arterioscler. Thromb. Vasc. Biol. 2017, 37, 2161-2170. [CrossRef]

55. Batra, R.; Suh, M.K.; Carson, J.S.; Dale, M.A.; Meisinger, T.M.; Fitzgerald, M.; Opperman, P.J.; Luo, J.; Pipinos, I.I.; Xiong, W.; et al. IL-1beta (Interleukin-1beta) and TNF-alpha (Tumor Necrosis Factor-alpha) Impact Abdominal Aortic Aneurysm Formation by Differential Effects on Macrophage Polarization. Arterioscler. Thromb. Vasc. Biol. 2018, 38, 457-463. [CrossRef] [PubMed]

56. Meher, A.K.; Spinosa, M.; Davis, J.P.; Pope, N.; Laubach, V.E.; Su, G.; Serbulea, V.; Leitinger, N.; Ailawadi, G.; Upchurch, G.R., Jr. Novel Role of IL (Interleukin)-1beta in Neutrophil Extracellular Trap Formation and Abdominal Aortic Aneurysms. Arterioscler. Thromb. Vasc. Biol. 2018, 38, 843-853. [CrossRef]

57. He, L.; Fu, Y.; Deng, J.; Shen, Y.; Wang, Y.; Yu, F.; Xie, N.; Chen, Z.; Hong, T.; Peng, X.; et al. Deficiency of FAM3D (Family With Sequence Similarity 3, Member D), A Novel Chemokine, Attenuates Neutrophil Recruitment and Ameliorates Abdominal Aortic Aneurysm Development. Arterioscler. Thromb. Vasc. Biol. 2018, 38, 1616-1631. [CrossRef] 
58. Umebayashi, R.; Uchida, H.A.; Kakio, Y.; Subramanian, V.; Daugherty, A.; Wada, J. Cilostazol attenuates angiotensin II-induced abdominal aortic aneurysms but not atherosclerosis in apolipoprotein E-deficient mice. Arterioscler. Thromb. Vasc. Biol. 2018, 38, 903-912. [CrossRef]

59. Li, J.; Xia, N.; Wen, S.; Li, D.; Lu, Y.; Gu, M.; Tang, T.; Jiao, J.; Lv, B.; Nie, S.; et al. IL (Interleukin)-33 Suppresses Abdominal Aortic Aneurysm by Enhancing Regulatory T-Cell Expansion and Activity. Arterioscler. Thromb. Vasc. Biol. 2019, 39, 446-458. [CrossRef]

60. Salmon, M.; Schaheen, B.; Spinosa, M.; Montgomery, W.; Pope, N.H.; Davis, J.P.; Johnston, W.F.; Sharma, A.K.; Owens, G.K.; Merchant, J.L.; et al. ZFP148 (Zinc-Finger Protein 148) binds cooperatively with NF-1 (Neurofibromin 1) to inhibit smooth muscle marker gene expression during abdominal aortic aneurysm formation. Arterioscler. Thromb. Vasc. Biol. 2019, 39, 73-88. [CrossRef]

61. Moran, C.S.; Biros, E.; Krishna, S.M.; Wang, Y.; Tikellis, C.; Morton, S.K.; Moxon, J.V.; Cooper, M.E.; Norman, P.E.; Burrell, L.M.; et al. Resveratrol inhibits growth of experimental abdominal aortic aneurysm associated with upregulation of angiotensinconverting enzyme 2. Arterioscler. Thromb. Vasc. Biol. 2017, 37, 2195-2203. [CrossRef] [PubMed]

62. Ortega, R.; Collado, A.; Selles, F.; Gonzalez-Navarro, H.; Sanz, M.J.; Real, J.T.; Piqueras, L. SGLT-2 (Sodium-Glucose Cotransporter 2) inhibition reduces Ang II (angiotensin II)-induced dissecting abdominal aortic aneurysm in apoE (apolipoprotein E) knockout mice. Arterioscler. Thromb. Vasc. Biol. 2019, 39, 1614-1628. [CrossRef] [PubMed]

63. Sudhahar, V.; Das, A.; Horimatsu, T.; Ash, D.; Leanhart, S.; Antipova, O.; Vogt, S.; Singla, B.; Csanyi, G.; White, J.; et al. Copper Transporter ATP7A (Copper-Transporting P-Type ATPase/Menkes ATPase) Limits Vascular Inflammation and Aortic Aneurysm Development: Role of MicroRNA-125b. Arterioscler. Thromb. Vasc. Biol. 2019, 39, 2320-2337. [CrossRef] [PubMed]

64. Yang, G.; Zhang, J.; Jiang, T.; Monslow, J.; Tang, S.Y.; Todd, L.; Pure, E.; Chen, L.; FitzGerald, G.A. Bmal1 Deletion in Myeloid Cells Attenuates Atherosclerotic Lesion Development and Restrains Abdominal Aortic Aneurysm Formation in Hyperlipidemic Mice. Arterioscler. Thromb. Vasc. Biol. 2020, 40, 1523-1532. [CrossRef]

65. Hiromi, T.; Yokoyama, U.; Kurotaki, D.; Mamun, A.; Ishiwata, R.; Ichikawa, Y.; Nishihara, H.; Umemura, M.; Fujita, T.; Yasuda, S.; et al. Excessive EP4 Signaling in Smooth Muscle Cells Induces Abdominal Aortic Aneurysm by Amplifying Inflammation. Arterioscler. Thromb. Vasc. Biol. 2020, 40, 1559-1573. [CrossRef]

66. Chang, Z.; Zhao, G.; Zhao, Y.; Lu, H.; Xiong, W.; Liang, W.; Sun, J.; Wang, H.; Zhu, T.; Rom, O.; et al. BAF60a Deficiency in Vascular Smooth Muscle Cells Prevents Abdominal Aortic Aneurysm by Reducing Inflammation and Extracellular Matrix Degradation. Arterioscler. Thromb. Vasc. Biol. 2020, 40, 2494-2507. [CrossRef]

67. Yang, H.; Zhou, T.; Sorenson, C.M.; Sheibani, N.; Liu, B. Myeloid-derived TSP1 (Thrombospondin-1) contributes to abdominal aortic aneurysm through suppressing tissue inhibitor of metalloproteinases-1. Arterioscler. Thromb. Vasc. Biol. 2020, 40, e350-e366. [CrossRef]

68. Yu, B.; Liu, Z.; Fu, Y.; Wang, Y.; Zhang, L.; Cai, Z.; Yu, F.; Wang, X.; Zhou, J.; Kong, W. CYLD Deubiquitinates Nicotinamide Adenine Dinucleotide Phosphate Oxidase 4 Contributing to Adventitial Remodeling. Arterioscler. Thromb. Vasc. Biol. 2017, 37, 1698-1709. [CrossRef]

69. Zheng, L.; Xing, L.; Zeng, C.; Wu, T.; Gui, Y.; Li, W.; Lan, T.; Yang, Y.; Gu, Q.; Qi, C.; et al. Inactivation of PI3Kdelta induces vascular injury and promotes aneurysm development by upregulating the AP-1/MMP-12 pathway in macrophages. Arterioscler. Thromb. Vasc. Biol. 2015, 35, 368-377. [CrossRef] [PubMed]

70. Krishna, S.M.; Seto, S.W.; Jose, R.J.; Biros, E.; Moran, C.S.; Wang, Y.; Clancy, P.; Golledge, J. A peptide antagonist of thrombospondin-1 promotes abdominal aortic aneurysm progression in the angiotensin II-infused apolipoprotein-E-deficient mouse. Arterioscler. Thromb. Vasc. Biol. 2015, 35, 389-398. [CrossRef] [PubMed]

71. Webb, N.R.; De Beer, M.C.; Wroblewski, J.M.; Ji, A.; Bailey, W.; Shridas, P.; Charnigo, R.J.; Noffsinger, V.P.; Witta, J.; Howatt, D.A.; et al. Deficiency of Endogenous Acute-Phase Serum Amyloid A Protects apoE-/- Mice from Angiotensin II-Induced Abdominal Aortic Aneurysm Formation. Arterioscler. Thromb. Vasc. Biol. 2015, 35, 1156-1165. [CrossRef] [PubMed]

72. Owens, A.P.r.; Edwards, T.L.; Antoniak, S.; Geddings, J.E.; Jahangir, E.; Wei, W.Q.; Denny, J.C.; Boulaftali, Y.; Bergmeier, W.; Daugherty, A.; et al. Platelet Inhibitors Reduce Rupture in a Mouse Model of Established Abdominal Aortic Aneurysm. Arterioscler. Thromb. Vasc. Biol. 2015, 35, 2032-2041. [CrossRef] [PubMed]

73. Ijaz, T.; Sun, H.; Pinchuk, I.V.; Milewicz, D.M.; Tilton, R.G.; Brasier, A.R. Deletion of NF-kappaB/RelA in angiotensin II-sensitive mesenchymal cells blocks aortic vascular inflammation and abdominal aortic aneurysm formation. Arterioscler. Thromb. Vasc. Biol. 2017, 37, 1881-1890. [CrossRef] [PubMed]

74. Lareyre, F.; Clement, M.; Raffort, J.; Pohlod, S.; Patel, M.; Esposito, B.; Master, L.; Finigan, A.; Vandestienne, M.; Stergiopulos, N.; et al. TGFbeta (Transforming Growth Factor-beta) Blockade Induces a Human-Like Disease in a Nondissecting Mouse Model of Abdominal Aortic Aneurysm. Arterioscler. Thromb. Vasc. Biol. 2017, 37, 2171-2181. [CrossRef]

75. Adam, M.; Kooreman, N.; Jagger, A.; Wagenhaeuser, M.U.; Mehrkens, D.; Wang, Y.; Kayama, Y.; Toyama, K.; Raaz, U.; Schellinger I.N.; et al. Systemic upregulation of IL-10 (Interleukin-10) using a nonimmunogenic vector reduces growth and rate of dissecting abdominal aortic aneurysm. Arterioscler. Thromb. Vasc. Biol. 2018, 38, 1796-1805. [CrossRef]

76. Zhong, L.; He, X.; Si, X.; Wang, H.; Li, B.; Hu, Y.; Li, M.; Chen, X.; Liao, W.; Liao, Y.; et al. SM22alpha (Smooth Muscle 22alpha) Prevents Aortic Aneurysm Formation by Inhibiting Smooth Muscle Cell Phenotypic Switching through Suppressing Reactive Oxygen Species/NF-kappaB (Nuclear Factor-kappaB). Arterioscler. Thromb. Vasc. Biol. 2019, 39, e10-e25. [CrossRef]

77. Sharma, N.; Dev, R.; Belenchia, A.M.; Aroor, A.R.; Whaley-Connell, A.; Pulakat, L.; Hans, C.P. Deficiency of IL12p40 (Interleukin 12 p40) Promotes Ang II (Angiotensin II)-Induced Abdominal Aortic Aneurysm. Arterioscler. Thromb. Vasc. Biol. 2019, 39, 212-223. [CrossRef] 
78. Xu, B.; Iida, Y.; Glover, K.J.; Ge, Y.; Wang, Y.; Xuan, H.; Hu, X.; Tanaka, H.; Wang, W.; Fujimura, N.; et al. Inhibition of VEGF (Vascular Endothelial Growth Factor)-A or its Receptor Activity Suppresses Experimental Aneurysm Progression in the Aortic Elastase Infusion Model. Arterioscler. Thromb. Vasc. Biol. 2019, 39, 1652-1666. [CrossRef] [PubMed]

79. Li, Z.; Zhao, Z.; Cai, Z.; Sun, Y.; Li, L.; Yao, F.; Yang, L.; Zhou, Y.; Zhu, H.; Fu, Y.; et al. Runx2 (Runt-Related Transcription Factor 2)-Mediated Microcalcification Is a Novel Pathological Characteristic and Potential Mediator of Abdominal Aortic Aneurysm. Arterioscler. Thromb. Vasc. Biol. 2020, 40, 1352-1369. [CrossRef]

80. Jana, S.; Chute, M.; Hu, M.; Winkelaar, G.; Owen, C.A.; Oudit, G.Y.; Kassiri, Z. ADAM (a Disintegrin and Metalloproteinase) 15 Deficiency Exacerbates Ang II (Angiotensin II)-Induced Aortic Remodeling Leading to Abdominal Aortic Aneurysm. Arterioscler. Thromb. Vasc. Biol. 2020, 40, 1918-1934. [CrossRef]

81. Chiang, M.T.; Chen, I.M.; Hsu, F.F.; Chen, Y.H.; Tsai, M.S.; Hsu, Y.W.; Leu, H.B.; Huang, P.H.; Chen, J.W.; Liu, F.T.; et al. Gal-1 (Galectin-1) Upregulation Contributes to Abdominal Aortic Aneurysm Progression by Enhancing Vascular Inflammation. Arterioscler. Thromb. Vasc. Biol. 2021, 41, 331-345. [CrossRef] [PubMed]

82. Daugherty, A.; Cassis, L.A. Mouse models of abdominal aortic aneurysms. Arterioscler. Thromb. Vasc. Biol. 2004, $24,429-434$. [CrossRef] [PubMed]

83. Wang, Y.; Krishna, S.; Golledge, J. The calcium chloride-induced rodent model of abdominal aortic aneurysm. Atherosclerosis 2013, 226, 29-39. [CrossRef] [PubMed]

84. Rateri, D.L.; Davis, F.M.; Balakrishnan, A.; Howatt, D.A.; Moorleghen, J.J.; O'Connor, W.N.; Charnigo, R.; Cassis, L.A.; Daugherty, A. Angiotensin II induces region-specific medial disruption during evolution of ascending aortic aneurysms. Am. J. Pathol. 2014, 184, 2586-2595. [CrossRef]

85. Sawada, H.; Lu, H.S.; Cassis, L.A.; Daugherty, A. Twenty Years of Studying AngII (Angiotensin II)-Induced Abdominal Aortic Pathologies in Mice: Continuing Questions and Challenges to Provide Insight into the Human Disease. Arterioscler. Thromb. Vasc. Biol. 2022, 42. [CrossRef]

86. Bersi, M.R.; Acosta Santamaria, V.A.; Marback, K.; Di Achille, P.; Phillips, E.H.; Goergen, C.J.; Humphrey, J.D.; Avril, S. Multimodality Imaging-Based Characterization of Regional Material Properties in a Murine Model of Aortic Dissection. Sci. Rep. 2020, 10, 9244. [CrossRef]

87. Brangsch, J.; Reimann, C.; Kaufmann, J.O.; Adams, L.C.; Onthank, D.C.; Thone-Reineke, C.; Robinson, S.P.; Buchholz, R.; Karst, U.; Botnar, R.M.; et al. Concurrent Molecular Magnetic Resonance Imaging of Inflammatory Activity and Extracellular Matrix Degradation for the Prediction of Aneurysm Rupture. Circ. Cardiovasc. Imaging 2019, 12, e008707. [CrossRef]

88. du Plessis, A.; Broeckhoven, C.; Guelpa, A.; le Roux, S.G. Laboratory x-ray micro-computed tomography: A user guideline for biological samples. Gigascience 2017, 6, 1-11. [CrossRef]

89. Willekens, I.; Buls, N.; Lahoutte, T.; Baeyens, L.; Vanhove, C.; Caveliers, V.; Deklerck, R.; Bossuyt, A.; de Mey, J. Evaluation of the radiation dose in micro-CT with optimization of the scan protocol. Contrast Media Mol. Imaging 2010, 5, 201-207. [CrossRef]

90. Klink, A.; Heynens, J.; Herranz, B.; Lobatto, M.E.; Arias, T.; Sanders, H.M.; Strijkers, G.J.; Merkx, M.; Nicolay, K.; Fuster, V.; et al. In vivo characterization of a new abdominal aortic aneurysm mouse model with conventional and molecular magnetic resonance imaging. J. Am. Coll. Cardiol. 2011, 58, 2522-2530. [CrossRef]

91. Turner, G.H.; Olzinski, A.R.; Bernard, R.E.; Aravindhan, K.; Karr, H.W.; Mirabile, R.C.; Willette, R.N.; Gough, P.J.; Jucker, B.M In vivo serial assessment of aortic aneurysm formation in apolipoprotein E-deficient mice via MRI. Circ. Cardiovasc. Imaging 2008, 1, 220-226. [CrossRef] [PubMed]

92. Ferruzzi, J.; Murtada, S.I.; Li, G.; Jiao, Y.; Uman, S.; Ting, M.Y.; Tellides, G.; Humphrey, J.D. Pharmacologically Improved Contractility Protects Against Aortic Dissection in Mice with Disrupted Transforming Growth Factor-beta Signaling Despite Compromised Extracellular Matrix Properties. Arterioscler. Thromb. Vasc. Biol. 2016, 36, 919-927. [CrossRef] [PubMed]

93. Clement, M.; Chappell, J.; Raffort, J.; Lareyre, F.; Vandestienne, M.; Taylor, A.L.; Finigan, A.; Harrison, J.; Bennett, M.R.; Bruneval, P.; et al. Vascular Smooth Muscle Cell Plasticity and Autophagy in Dissecting Aortic Aneurysms. Arterioscler. Thromb. Vasc. Biol. 2019, 39, 1149-1159. [CrossRef] [PubMed]

94. Pan, L.; Lin, Z.; Tang, X.; Tian, J.; Zheng, Q.; Jing, J.; Xie, L.; Chen, H.; Lu, Q.; Wang, H.; et al. S-Nitrosylation of Plastin-3 Exacerbates Thoracic Aortic Dissection Formation via Endothelial Barrier Dysfunction. Arterioscler. Thromb. Vasc. Biol. 2020, 40, 175-188. [CrossRef]

95. Nishida, N.; Aoki, H.; Ohno-Urabe, S.; Nishihara, M.; Furusho, A.; Hirakata, S.; Hayashi, M.; Ito, S.; Yamada, H.; Hirata, Y.; et al. High salt intake worsens aortic dissection in mice: Involvement of IL (interleukin)-17A-dependent ECM (extracellular matrix) metabolism. Arterioscler. Thromb. Vasc. Biol. 2020, 40, 189-205. [CrossRef] [PubMed]

96. Trachet, B.; Fraga-Silva, R.A.; Jacquet, P.A.; Stergiopulos, N.; Segers, P. Incidence, severity, mortality, and confounding factors for dissecting AAA detection in angiotensin II-infused mice: A meta-analysis. Cardiovasc. Res. 2015, 108, 159-170. [CrossRef]

97. Ito, S.; Hashimoto, Y.; Majima, R.; Nakao, E.; Aoki, H.; Nishihara, M.; Ohno-Urabe, S.; Furusho, A.; Hirakata, S.; Nishida, N.; et al. MRTF-A promotes angiotensin II-induced inflammatory response and aortic dissection in mice. PLoS ONE 2020, 15, e0229888. [CrossRef]

98. Gage, G.J.; Kipke, D.R.; Shain, W. Whole animal perfusion fixation for rodents. J. Vis. Exp. 2012, 65, 3564. [CrossRef]

99. Gallo, E.M.; Loch, D.C.; Habashi, J.P.; Calderon, J.F.; Chen, Y.; Bedja, D.; van Erp, C.; Gerber, E.E.; Parker, S.J.; Sauls, K.; et al. Angiotensin II-dependent TGF-beta signaling contributes to Loeys-Dietz syndrome vascular pathogenesis. J. Clin. Investig. 2014, 124, 448-460. [CrossRef] [PubMed] 
100. Habashi, J.P.; Judge, D.P.; Holm, T.M.; Cohn, R.D.; Loeys, B.L.; Cooper, T.K.; Myers, L.; Klein, E.C.; Liu, G.; Calvi, C.; et al. Losartan, an AT1 antagonist, prevents aortic aneurysm in a mouse model of Marfan syndrome. Science 2006, 312, $117-121$. [CrossRef]

101. Lin, C.J.; Staiculescu, M.C.; Hawes, J.Z.; Cocciolone, A.J.; Hunkins, B.M.; Roth, R.A.; Lin, C.Y.; Mecham, R.P.; Wagenseil, J.E. Heterogeneous Cellular Contributions to Elastic Laminae Formation in Arterial Wall Development. Circ. Res. 2019, 125, 1006-1018. [CrossRef] [PubMed]

102. Trachet, B.; Aslanidou, L.; Piersigilli, A.; Fraga-Silva, R.A.; Sordet-Dessimoz, J.; Villanueva-Perez, P.; Stampanoni, M.F.M.; Stergiopulos, N.; Segers, P. Angiotensin II infusion into ApoE-/- mice: A model for aortic dissection rather than abdominal aortic aneurysm? Cardiovasc. Res. 2017, 113, 1230-1242. [CrossRef] [PubMed]

103. Trachet, B.; Fraga-Silva, R.A.; Piersigilli, A.; Tedgui, A.; Sordet-Dessimoz, J.; Astolfo, A.; Van der Donckt, C.; Modregger, P.; Stampanoni, M.F.; Segers, P.; et al. Dissecting abdominal aortic aneurysm in Ang II-infused mice: Suprarenal branch ruptures and apparent luminal dilatation. Cardiovasc. Res. 2015, 105, 213-222. [CrossRef] [PubMed]

104. Bersi, M.R.; Bellini, C.; Humphrey, J.D.; Avril, S. Local variations in material and structural properties characterize murine thoracic aortic aneurysm mechanics. Biomech. Model. Mechanobiol. 2019, 18, 203-218. [CrossRef] [PubMed]

105. Ohno-Urabe, S.; Kukida, M.; Franklin, M.K.; Katsumata, Y.; Su, W.; Gong, M.C.; Lu, H.S.; Daugherty, A.; Sawada, H. Authentication of in situ measurements for thoracic aortic aneurysms in mice. Arterioscler. Thromb. Vasc. Biol. 2021, 41, $2117-2119$. [CrossRef]

106. He, C.; Jiang, B.; Wang, M.; Ren, P.; Murtada, S.I.; Caulk, A.W.; Li, G.; Qin, L.; Assi, R.; Lovoulos, C.J.; et al. mTOR inhibition prevents angiotensin II-induced aortic rupture and pseudoaneurysm but promotes dissection in Apoe-deficient mice. JCI Insight 2022, 7, e155815. [CrossRef]

107. Trachet, B.; Fraga-Silva, R.A.; Londono, F.J.; Swillens, A.; Stergiopulos, N.; Segers, P. Performance comparison of ultrasound-based methods to assess aortic diameter and stiffness in normal and aneurysmal mice. PLoS ONE 2015, 10, e0129007. [CrossRef]

108. Waduud, M.A.; Kandavelu, P.; Reay, M.; Paradine, K.; Scott, D.J.A.; Bailey, M.A. High-Frequency Three-Dimensional Lumen Volume Ultrasound Is a Sensitive Method to Detect Early Aneurysmal Change in Elastase-Induced Murine Abdominal Aortic Aneurysm. Aorta 2021, 9, 215-220. [CrossRef] [PubMed]

109. Pereira, L.; Lee, S.Y.; Gayraud, B.; Andrikopoulos, K.; Shapiro, S.D.; Bunton, T.; Biery, N.J.; Dietz, H.C.; Sakai, L.Y.; Ramirez, F. Pathogenetic sequence for aneurysm revealed in mice underexpressing fibrillin-1. Proc. Natl. Acad. Sci. USA 1999, 96, 3819-3823. [CrossRef] [PubMed]

110. Yang, P.; Schmit, B.M.; Fu, C.; DeSart, K.; Oh, S.P.; Berceli, S.A.; Jiang, Z. Smooth muscle cell-specific Tgfbr1 deficiency promotes aortic aneurysm formation by stimulating multiple signaling events. Sci. Rep. 2016, 6, 35444. [CrossRef]

111. Li, W.; Li, Q.; Jiao, Y.; Qin, L.; Ali, R.; Zhou, J.; Ferruzzi, J.; Kim, R.W.; Geirsson, A.; Dietz, H.C.; et al. Tgfbr2 disruption in postnatal smooth muscle impairs aortic wall homeostasis. J. Clin. Investig. 2014, 124, 755-767. [CrossRef] [PubMed]

112. Chen, J.Z.; Sawada, H.; Moorleghen, J.J.; Weiland, M.; Daugherty, A.; Sheppard, M.B. Aortic strain correlates with elastin fragmentation in Fibrillin-1 hypomorphic mice. Circ. Rep. 2019, 1, 199-205. [CrossRef] [PubMed]

113. Adelsperger, A.R.; Phillips, E.H.; Ibriga, H.S.; Craig, B.A.; Green, L.A.; Murphy, M.P.; Goergen, C.J. Development and growth trends in angiotensin II-induced murine dissecting abdominal aortic aneurysms. Physiol. Rep. 2018, 6, e13668. [CrossRef] [PubMed]

114. Goldberg, A.; Pakkiri, P.; Dai, E.; Lucas, A.; Fenster, A. Measurements of aneurysm morphology determined by 3-d microultrasound imaging as potential quantitative biomarkers in a mouse aneurysm model. Ultrasound Med. Biol. 2007, 33, 1552-1560. [CrossRef]

115. Soepriatna, A.H.; Damen, F.W.; Vlachos, P.P.; Goergen, C.J. Cardiac and respiratory-gated volumetric murine ultrasound. Int. J. Cardiovasc. Imaging 2018, 34, 713-724. [CrossRef]

116. Yrineo, A.A.; Adelsperger, A.R.; Durkes, A.C.; Distasi, M.R.; Voytik-Harbin, S.L.; Murphy, M.P.; Goergen, C.J. Murine ultrasoundguided transabdominal para-aortic injections of self-assembling type I collagen oligomers. J. Control. Release 2017, $249,53-62$. [CrossRef]

117. Cebull, H.; Soepriatna, A.; Boyle, J.; Rothenberger, S.; Goergen, C. Strain mapping from 4D ultrasound reveals complex remodeling in dissecting murine abdominal aortic aneurysms. J. Biomech. Eng. 2019, 141, 060907. [CrossRef]

118. Cao, R.Y.; Amand, T.; Ford, M.D.; Piomelli, U.; Funk, C.D. The Murine Angiotensin II-Induced Abdominal Aortic Aneurysm Model: Rupture Risk and Inflammatory Progression Patterns. Front. Pharm. 2010, 1, 9. [CrossRef]

119. Ford, M.D.; Black, A.T.; Cao, R.Y.; Funk, C.D.; Piomelli, U. Hemodynamics of the mouse abdominal aortic aneurysm. J. Biomech. Eng. 2011, 133, 121008. [CrossRef]

120. Lee, L.; Cui, J.Z.; Cua, M.; Esfandiarei, M.; Sheng, X.; Chui, W.A.; Xu, M.H.; Sarunic, M.V.; Beg, M.F.; van Breemen, C.; et al. Aortic and cardiac structure and function using high-resolution echocardiography and optical coherence tomography in a mouse model of Marfan syndrome. PLoS ONE 2016, 11, e0164778. [CrossRef]

121. Lange, C.; Sommerfeld, M.; Namsolleck, P.; Kintscher, U.; Unger, T.; Kaschina, E. AT2R (Angiotensin AT2 Receptor) Agonist, Compound 21, Prevents Abdominal Aortic Aneurysm Progression in the Rat. Hypertension 2018, 72, e20-e29. [CrossRef] [PubMed]

122. Phillips, E.H.; Yrineo, A.A.; Schroeder, H.D.; Wilson, K.E.; Cheng, J.X.; Goergen, C.J. Morphological and Biomechanical Differences in the Elastase and AngII apoE (-/-) Rodent Models of Abdominal Aortic Aneurysms. Biomed. Res. Int. 2015, 2015, 413189. [CrossRef] [PubMed] 
123. Di Lascio, N.; Kusmic, C.; Stea, F.; Faita, F. Ultrasound-based Pulse Wave Velocity Evaluation in Mice. J. Vis. Exp. 2017, 120 , 54362. [CrossRef] [PubMed]

124. Di Lascio, N.; Stea, F.; Kusmic, C.; Sicari, R.; Faita, F. Non-invasive assessment of pulse wave velocity in mice by means of ultrasound images. Atherosclerosis 2014, 237, 31-37. [CrossRef]

125. Luo, J.; Fujikura, K.; Tyrie, L.S.; Tilson, M.D.; Konofagou, E.E. Pulse wave imaging of normal and aneurysmal abdominal aortas in vivo. IEEE Trans. Med. Imaging 2009, 28, 477-486.

126. Nandlall, S.D.; Goldklang, M.P.; Kalashian, A.; Dangra, N.A.; D'Armiento, J.M.; Konofagou, E.E. Monitoring and staging abdominal aortic aneurysm disease with pulse wave imaging. Ultrasound Med. Biol. 2014, 40, 2404-2414. [CrossRef] 